\title{
Effect of Organic Manure on the Growth and Yield of Fluted Pumpkin (Telfairia Occidentalis Hook. F.) in Unwana
}

\author{
Umekwe P.N., Eneruvie B.E., Okpani F.M.
}

\begin{abstract}
An experiment was conducted at teaching, demonstration and research (TDR) farm of Department of Horticulture and Landscape Technology, Akanu Ibiam Federal Polytechnic, Unwana-Afikpo during 2018 cropping season, to evaluate the effect of organic manure on the growth and yield of fluted pumpkin (Telfairia occidentalis Hook. F.) in Unwana. Three different organic manures (cow dung, poultry droppings and goat manure) were used. The treatments were laid in a Randomized Complete Block Design (RCBD) with three replications. Parameters measured were: vine length, number of leaves, number of vines, leaf area, stem girth, fresh weight of leaves and leaf yield. The result of the experiment showed significant differences $(P=0.05)$ in vine length, number of leaves, number of vines, weight of leaves and leaf yield. The longest vine $(156.40 \mathrm{~cm})$, highest number of leaves $(36.93)$, highest number of vine $(11.76)$, fresh weight of leaves $(2.083 \mathrm{~kg})$ and leaf yield $(94.80$ ton/ha) was recorded at poultry manure plot. Control plot obtained the least values in all parameters assessed. Therefore, based on the result of this finding, it is hereby recommended that the use of poultry manure should be adopted by farmers for profitable fluted pumpkin production in the study area.
\end{abstract}

Index Terms - Fluted Pumpkin, Organic Manure, Poultry Manure and Yield

\section{INTRODUCTION}

Fluted pumpkin (Telfairia occidentalis Hook. F.) originated from West Africa and is found in the forest zone of west and central Africa, especially in Benin, Nigeria and Cameroun [1]. It is a popular vegetable all over Nigeria. The crop is a perennial dioecious climbing herb and it is cultivated as annual crops under the traditional farming system of West Africa [2], [3]. Fluted pumpkin is usually propagated by seed and might grow to a height of more than $8 \mathrm{~m}$. The leaves may be greenish, reddish or yellowish in colour and usually covered with white bloom [2], [4]. Fluted pumpkin grows fast in a loose friable soil with ample humus and produces edible leaves in the rainy season and at the beginning of the dry

Mr. Umekwe, P. N. (B. Agric., M.Sc. in view) in Ebonyi State University, Abakaliki, Ebonyi State: Corresponding author Major: Horticulture. Affiliation; Department of Horticulture and Landscape Technology, Akanu Ibiam Federal Polytechnic, Unwana-Afikpo, Ebonyi State, Nigeria

Mr. Eneruvie, B. E. (B. Agric., PGDE, M.Sc.): Major: Animal Nutrition and Biochemistry. Affiliation; Department of Agricultural Technology, Akanu Ibiam Federal Polytechnic, Unwana-Afikpo, Ebonyi State, Nigeria

Mrs. Okpani, F. M. (B. Agric., PGD in view) in Michael Okpara University of Agriculture, Umudike, Abia State: Major: Agronomy. Affiliation; Department of Horticulture and Landscape Technology, Akanu Ibiam Federal Polytechnic, Unwana-Afikpo, Ebonyi State, season. It can grow on a wide variety of soil condition and managed as a short term perennial crop when grown on well drained soil [3], [5].

Despite the increasing relevance and high demand for Telfairia occidentalis in Nigeria, there is no standard practice with respect to application of organic manure. Awodun [6] reported that quality of fluted pumpkin in terms of nutrient availability increase mostly when cultivated in good fertile soils rich in N, P and $\mathrm{K}$. The use of organic manure especially poultry manure increased number of nodules and yield in cowpea and also used as amendment of degraded soils [7]. Awodun [6] also noted that poultry manure increases N, P, K, $\mathrm{Ca}$ and $\mathrm{Mg}$ content in the leaves fluted pumpkin. Smith [8] reported that poultry manure resulted in higher number of root and shoot than NPK fertilizer treatments on tomato. Therefore, this study was carried out to evaluate the effect of organic manure on the growth and yield of fluted pumpkin ( $T$. occidentalis Hook F) in Unwana.

\section{MATERIALS AND METHODS}

\section{A. Site Description:}

The experiment was conducted at teaching, demonstration and research (TDR) farm of Department of Horticulture and Landscape Technology, Akanu Ibiam Federal Polytechnic Unwana-Afikpo during 2018 cropping season. Unwana is located in latitude $06^{\circ} 5^{\prime} \mathrm{N}$ and longitude $08^{0} 03^{\prime} \mathrm{E}$ with an elevation of $300 \mathrm{~m}$ above sea level [9].

\section{B. Land Preparation:}

The experimental field was measured $11.5 \mathrm{~m}$ long by $10 \mathrm{~m}$ wide, giving a total of $115 \mathrm{~m}^{2}$. The field was cleared using cutlass. Plots measuring $2 \times 2\left(4 \mathrm{~m}^{2}\right)$ were marked out while tillage was carried out using hoe.

C. Pre-Planting Soil Analysis:

Soil samples were randomly collected from the site at 0 to $20 \mathrm{~cm}$ depth using the soil auger. The samples were bulked into a composite sample and send for physio-chemical properties analysis.

\section{Experimental Design:}

The experiment was laid out in randomized complete block design (RCBD). Each treatment was replicated three times and the treatment comprised of three different organic manure (poultry dropping, cow dung and goat manure).

\section{E. Seed Collection, Planting and Manure Application:}

Seeds of Telfairia occidentalis were collected from healthy pods of proven varieties among farmers in Afikpo. 
The seeds were planted two seeds per hole at the depth of 3 to $4 \mathrm{~cm}$ with a spacing of $50 \mathrm{~cm}$ by $50 \mathrm{~cm}$. Cured organic manure (poultry, cow and goat) was incorporated at $10 \mathrm{~kg}$ each into the soil based on plots allotted during tilling for rapid decomposition and nutrient release to the crop. Weeding was done at $3 \mathrm{WAS}$ and subsequently as the need arose.

\section{F. Data Collection and Analysis:}

The experiment was observed and the following parameters were recorded: Vine length, Number of leaves, Number of vines, Stem girth, Leaf area, Fresh weight of leaf and leaf yield. Leaf yield was calculated thus:

Leaf yield $($ ton $/$ ha $)=$ Number of leaves/plot $\times 10000 \mathrm{~m}^{2}$ /area of plot $\times 1000 \mathrm{~kg}$

Data collected from the study was subjected to analysis of variance and treatment means were separated using LSD at $5 \%$ level of probability [10].

\section{RESULTS}

Physico-Chemical Properties of the Soil of the Experimental Site and Organic Manure:

Physico-chemical properties of the soil of the study area are shown in Table 1. The result showed that the soil is sandy loam with very low $\mathrm{N}$ and exchangeable calcium. The initial soil $\mathrm{pH}$ was acidic. The initial poultry $\mathrm{pH}$ was alkaline whereas goat and cow manure was highly acidic with very low $\mathrm{N}$ and exchangeable cations. Poultry manure have high $\mathrm{N}$ $(4.50 \%)$, percent organic carbon was high in poultry when compared to other dung's used.

Table 1: Physico-Chemical Properties of the Experimental Site and Organic Manure

\begin{tabular}{lllll}
\hline Elements & Soil & Poultry & Cow & Goat \\
\hline $\mathrm{pH}\left(\mathrm{H}_{2} \mathrm{O}\right)$ & 5.00 & 8.12 & 6.40 & 6.60 \\
$\mathrm{Mg}(\mathrm{Cmol} / \mathrm{kg})$ & 0.52 & 0.42 & 0.87 & 0.42 \\
$\mathrm{Na}(\mathrm{Cmol} / \mathrm{kg})$ & 0.02 & 0.35 & 0.30 & 0.26 \\
$\mathrm{Ca}(\mathrm{Cmol} / \mathrm{kg})$ & 2.20 & 5.20 & 1.10 & 0.63 \\
$\mathrm{~K}(\mathrm{Cmol} / \mathrm{kg})$ & 0.01 & 6.25 & 1.10 & 0.17 \\
$\mathrm{P}(\mathrm{Cmol} / \mathrm{kg})$ & 3.62 & 0.31 & 4.50 & 4.80 \\
$\%$ Organic C & 1.26 & 46.80 & 16.85 & 16.90 \\
$\%$ Organic $\mathrm{N}$ & 0.02 & 4.50 & 2.10 & 2.40 \\
Sand & 89.52 & 0.00 & 0.00 & 0.00 \\
Silt & 7.00 & 0.00 & 0.00 & 0.00 \\
Clay & 3.48 & 0.00 & 0.00 & 0.00 \\
Textural Class & Sandy Loam & 0.00 & 0.00 & 0.00 \\
\hline
\end{tabular}

Use italics for emphasis; do not underline.

\section{A. Vine Length (cm)}

Vine length of fluted pumpkin was significantly affected $(\mathrm{P}=0.05)$ by application of organic manure. Poultry manure treatment produced longest vine of $156.40 \mathrm{~cm}$ that differed significantly from control plots and were statistically similar with vine length recorded at cow $(145.80 \mathrm{~cm})$ and goat $(140.90 \mathrm{~cm})$ treatment as presented in Table 2.

\section{B. Number of Leaves}

Poultry manure produced the highest number of leaves of approximately 37 leaves that were statistically similar with other treatments used except at control plots with approximately 32 leaves that gave the least number of leaves (Table 2).

\section{Number of Vines}

Number of vines of approximately 12 vines produced at poultry manure treatment differed significantly from other treatments used except cow manure with 11 vines where they are statistically the same (Table 2).

D. Leaf Area $\left(\mathrm{cm}^{2}\right)$
The result in Table 2 shows that organic manure was non-significant at $\mathrm{P}=0.05$ on the leaf area produced. Plots with goat manure produced broader leaves of $122.90 \mathrm{~cm}^{2}$ while control plot gave the lowest leaf area of $92.07 \mathrm{~cm}^{2}$.

\section{E. Stem Girth (cm)}

Stem girth produced from the experiment were statistically the same. Although, Cow manure plot produced the longest stem of $0.738 \mathrm{~cm}$ and the control plot recorded the least girth of $0.633 \mathrm{~cm}$ (Table 2).

\section{F. Fresh Weight of Leaves $(\mathrm{kg})$}

In Table 2, poultry manure plots recorded heaviest leaves of $2.083 \mathrm{~kg}$ which differed significantly from other treatments used, followed by goat manure treatments with $1.867 \mathrm{~kg}$.

\section{G. Leaf Yield (ton/ha)}

The highest leaf yield of fluted pumpkin was obtained at poultry manure plots $(94.50 \mathrm{t} / \mathrm{ha})$ while control plots gave the lowest yield of $83.67 \mathrm{t} / \mathrm{ha}$ and they differed significantly (Table 2). Poultry manure plots gave highest yield of $94.50 \mathrm{t} / \mathrm{ha}$, followed by cow manure and goat manure (91.33t/ha and $89.49 \mathrm{t} / \mathrm{ha})$, respectively and statistically the same. 
Table 2: Effects of Organic Manure on the Growth and Yield Parameters of Fluted Pumpkin

\begin{tabular}{lccccccc}
\hline Treatment VL & NL & NV & LA & SG & FWL & LY \\
\hline Control $118.900^{\mathrm{b}}$ & $31.860^{\mathrm{b}}$ & $9.390^{\mathrm{b}}$ & $92.700^{\mathrm{a}}$ & $0.633^{\mathrm{a}}$ & $1.233^{\mathrm{d}}$ & $83.67^{\mathrm{b}}$ \\
Cow & $145.800^{\mathrm{a}}$ & $36.200^{\mathrm{a}}$ & $10.620^{\mathrm{a}}$ & $100.300^{\mathrm{a}}$ & $0.783^{\mathrm{a}}$ & $1.667 \mathrm{c}$ & $91.33^{\mathrm{a}}$ \\
Goat & $140.900^{\mathrm{a}}$ & $36.180^{\mathrm{a}}$ & $9.760^{\mathrm{b}}$ & $122.900^{\mathrm{a}}$ & $0.767^{\mathrm{a}}$ & $1.867^{\mathrm{b}}$ & $89.49^{\mathrm{a}}$ \\
Poultry & $156.400^{\mathrm{a}}$ & $36.930^{\mathrm{a}}$ & $11.760^{\mathrm{a}}$ & $99.000^{\mathrm{a}}$ & $0.756^{\mathrm{a}}$ & $2.083^{\mathrm{a}}$ & $94.50^{\mathrm{a}}$ \\
LSD & 23.020 & 2.890 & 1.632 & N.S & N.S & 0.1053 & 6.560 \\
\hline
\end{tabular}

Means in the same column having the same letter(s) are not significantly different at $(\mathrm{P}=0.05) ; \mathrm{LSD}=$ Least Significant Difference, $\mathrm{VL}=$ Vine Length $(\mathrm{cm}), \mathrm{NL}=$ Number of Leaves, $\mathrm{NV}=$ Number of Vines, LA= Leaf Area $\left(\mathrm{cm}^{2}\right), \mathrm{SG}=$ Stem Girth $(\mathrm{cm})$, FWL $=$ Fresh Weight of Leaves $(\mathrm{kg}), \mathrm{LY}=$ Leaf Yield (t/ha) and N.S= Non Significant

\section{DISCUSSION}

Most of the nutrients in the soil were below the critical level [11] making it necessary for the application of soil amendment in form of organic manure. The results of this field experiment shows that organic manure applications had significant effect on vine length, number of leaves and vines, fresh weight of leaves and leaf yield of fluted pumpkin produced. The longest vine, highest number of leaves and vines, heaviest leaves and leaf yield were obtained on plots grown with poultry manure. This is in conformity with work done by Eghball [12] and Munoz [13] who reported that animal manure is often readily available and may constitute a valuable source of nutrient. They also noted that poultry manure produces organic matter which can improve soil physical condition. This significant response of Telfairia to poultry manure application in terms of vine length, number of leaves and number of vines may be attributed to high nutrient absorption by the plant. These results are in agreement with the findings of Ayami [14]. Ndor [15] also noted that this may be as a result of higher availability of nitrogen in poultry manure which encourages higher vegetative growth.

The application of poultry manure gave the highest weight and leaf yield of Telfairia. This is in conformity with the report of Husseni [16] who observed that poultry manure is superior to other sources of organic manure. Umoetok [17] also noted an increase in leaf production of Telfairia as a result of beneficial effect of poultry manure.

\section{CONCLUSION}

Poultry manure improved the vegetative growth and yield of fluted pumpkin (Telfairia occidentalis Hook F.). The application of poultry manure was observed as the optimum agronomic practice to harness highest foliage production and thereby boost fluted pumpkin productivity. It is hereby recommended to farmers in this study area for a more profitable production of fluted pumpkin.

\section{DECLARATIONS}

All the experimental procedures were performed according to the ethical guidelines for research using agronomy studies established by the Ethical Committee of Akanu Ibiam Federal
Polytechnic, Unwana which is in compliance with guide for horticultural crop production.

Consent of Publication: All the authors unanimously consent to this publication.

Availability of Data and materials: The materials and data are available upon reasonable request from the corresponding author.

Competing Interest: There are no competing interests.

Funding: There was no funding. This research is part of field work of the corresponding author.

Author Contribution: (1). First author (UPN) wrote the topic of the research, sourced available literature for the work, designed the experiment and performed the research. (2). Second author (EBE) co-designed the experiment, brought and weighed the organic manures, analyze for their physic-chemical properties, supervised the research and proof read the manuscript (3). Third author (OFM) co- designed the experiment, proof read and corrected the manuscript.

\section{REFERENCES}

[1] B. E. Okoli, C. M. Mgbeogu, "Fluted Pumpkin (Telfairia occidentalis Hook. F.) West African Vegetable”. Economic Botany 1982, 3(7): 145-149.

[2] M. O. Akoroda, "Ethnobotany of Telfairia occidentalis (Cucurbitaceae) among Igbos of Nigeria”. Economic Botany 1988, 44(1): 29-39

[3] R. R. Schippers, “African Indigenous Vegetable: An Overview of the Cultivated Species ". Revised edition on CD-ROM. National Resources International Limited, Aylesford, United Kingdom, 2000.

[4] P. E. Ogbonna, Pod portion and type effects on sex, growth and yield of Fluted Pumpkin. Journal of African Crop Science. 2008, 16(3): 185-190

[5] M. O. Akoroda, E. Ogar, Seed production and breeding potential of fluted pumpkin (Telfairia occidentalis). Euphysical, 1990, 49(1): 25-32.

[6] M. A. Awodun, Effect of Poultry and Cattle Manure on the Growth, Yield and Nutrient Content of Fluted Pumpkin (T. occidentalis Hook F.). Asian Journal of Agricultural Research. 2007, 1(2): 67-73.

[7] D.K. Madukwe, I. E. C. Christo, and M. O. Onuh, Effect of organic manure and cowpea (Vigna unguiculata $\mathrm{L}$ ) varieties on the chemical properties of soil and root nodulation. Science World Journal 2008, 3(1): 43-46.

[8] M. A. K. Smith, O. A. Owolafe, A. K. Owanikin, Effect of poultry manure on weed growth and yield of Indian Spinach (B. alda) in humid tropics. Proceeding of the $35^{\text {th }}$ Annual Conference 2001. 
[9] NIMET Meteorological Station, Akanu Ibiam Federal Polytechnic, Unwana-Afikpo, Meteorological Bulletin, 2003.

[10] I. U. Obi, Fixed and random treatment models in analysis of variance for balance design. Department of Crop Science, University of Nigeria Nsukka. Star print and publishing Co, Enugu, Nigeria, 2001, 38pp.

[11] O. A. Adeoye, A. A. Agboola, Critical level of soil available P. K, Zn, $\mathrm{Mo}, \mathrm{Cu}$ and $\mathrm{Mn}$ on maize leaf content on sedimentary soil of South Western Nigeria. Fert. Res, 1985, 6:60-71

[12] B. Eghball, D. Counting, J. E. Gilley, Residual effects of manure and compost application on corn production and soil properties. Agronomy Journal, 2004, 96(92):442-447.

[13] G. R. Munoz, K. A. Kellin, J. M. Powell, P. E. Septh, Comparison of estimation of first year daily manure nitrogen availability or recovery using nitrogen IS and other techniques. Journal of Environmental Quality 2004, 33(2): 719-727.

[14] I. S. Ayami, Integrated Plant Nutrient Management. A panacea for sustainable crop production in Nigeria. Int. J. Soil Sci. 2011, 6:19-24.

[15] E. Ndor, O. O. Agbede, S. Dauda, Growth and yield response of cotton (Gossypium sp.) to varying levels of nitrogen and phosphorus fertilization on Southern Guinea Savanna zone, Nigeria. PAT December, 2010, 6(2):119-125.

[16] T. O. Husseni, Effect of Poultry Manure on the Growth of Tomato. Proceeding of $15^{\text {th }}$ Annual Conference of Hortson, NIHORT, Ibadan, Nigeria. 1997, Pp 43-48.

[17] S. Umoetok, A. Uko, B. Archibong, D. Ukeh, W. B. Binang, I. O. Ojating, Effects of application of inorganic fertilizer and poultry manure on insect pests and yield of Soybeans (Glycine max (L)) in the rainforest of Nigeria. Journal of Agricultural Science and Technology 2007, 10(1): 37-40. 